\title{
POJEM ARGUMENTÁCIE A JEHO DEFINÍCIA ${ }^{1}$
}

MARIÁN ZOUHAR, Filozofická fakulta Univerzity Komenského v Bratislave, Katedra logiky a metodológie vied, Bratislava, SR

ZOUHAR, M.: The Notion of Argumentation and Its Definition FILOZOFIA, 75, 2020, No 8, pp. $615-627$

\begin{abstract}
According to a rather widespread view, the substantive aim of argumentation consists in resolving differences of opinion between disputing parties. This is the core of the pragma-dialectical definition of argumentation. It is argued that the definition is too narrow, if applied outside the scope of the Pragma-Dialectical Theory. It is not the case that every instance of argumentation has to be aimed at resolving an explicit or implicit difference of opinion. This claim is based on situations in which it does not make good sense to construe the instances of argumentation as having the above aim. An alternative definition of argumentation, which is broader in scope, is suggested. Accordingly, argumentation is aimed at giving reasons for a standpoint in order to reach the communicative objectives that are relevant in a given situation.
\end{abstract}

Keywords: Aims of argumentation - Argumentation - Pragma-dialectical theory of argumentation - Resolving a difference of opinion

\section{1. Úvod}

Argumentácia je jedna z činností, ktoré sú typické pre racionálny diskurz. Využívame ju vtedy, ked' sa pokúšame podložit' nejaké stanovisko dôvodmi, pričom spravidla tak chceme ukázat', že stanovisko vykazuje vlastnosti, vd’aka ktorým s ním treba kognitívne (epistemicky, doxasticky) alebo konatívne počitat'. Takýmito vlastnostami môžu byt' pravdivost', správnost', prijatel'nost', presvedčivost' a podobne. Kognitívne počítat' so stanoviskom znamená považovat' ho za (kandidáta na) poznatok alebo zdôvodnené presvedčenie; konatívne počítat' so stanoviskom zase znamená považovat' ho za (kandidáta na) impulz ku konaniu. Pravda, vždy nie sme úspešní vo svojom úsilí ukázat', že isté stanovisko má spomenuté vlastnosti, no naše zlyhanie nemožno chápat' ako evidenciu o neexistencii zámeru dosiahnut' tento ciel'.

Pravdivost' alebo správnost' stanoviska sa líšia od jeho prijatel'nosti alebo presvedčivosti. Bez nároku na vyčerpávajúce vymedzenie možno povedat', že preukázat' pravdivost' alebo správnost' stanoviska spravidla znamená, že získa nárok na to, aby

\footnotetext{
${ }^{1}$ Ďakujem dvom anonymným recenzentom za dôkladné a podnetné pripomienky k predchádzajúcim verziám tohto článku, vd’aka ktorým som mohol odstránit' viaceré nedostatky.
} 
bolo zaradené do systému poznatkov, alebo aby sa konalo v súlade s ním, resp. aby sa zo systému odstránilo to, čo je s ním v konflikte. ${ }^{2}$ Opät bez nároku na vyčerpávajúce vymedzenie možno povedat', že preukázat' presvedčivost' alebo prijatel'nost' stanoviska spravidla znamená dosiahnut', že adresát argumentácie pod jej vplyvom upraví svoju databázu presvedčení, predpokladov, motívov konania a podobne tak, že stanovisko zaradí do svojej databázy, resp. odstráni z nej to, čo je s ním v konflikte.

Hoci argumentácia je všadeprítomná a každý s ňou má skúsenost' „z prvej ruky“", 3 jej teoretická reflexia je komplikovaná. Svedčí o tom nielen bohatá história, ktorá siaha k prvým systematickým úvahám o argumentoch a argumentácii u Aristotela či stoikov, ale aj desat'ročia najnovších výskumov, ktoré ponúkajú rôzne modely argumentácie $\mathrm{v}$ závislosti od toho, aký aspekt sa $\mathrm{v}$ nich akcentuje.

Zdá sa však, že napriek tomu je pomerne problematické identifikovat' tie atribúty argumentácie, ktoré možno pokladat' za kl'účové. Odráža sa to v návrhoch rozmanitých definícií argumentácie, z ktorých niektoré sú vel'mi jednoduché, iné zase pomerne zložité. Vynára sa legitímna otázka: pomocou akých atribútov možno pojem argumentácie definične vymedzit? K odpovedi na túto otázku sa prepracujem na základe kritickej analýzy jednej z významných definícií pojmu argumentácie, s ktorou sa môžeme v súčasnej literatúre stretnút'.

V druhej časti sformulujem spomenutú definíciu a načrtnem jej teoretický rámec. Táto definícia sa opiera o pojem riešenia názorovej nezhody medzi komunikačnými partnermi. V d'alšej časti sa zameriam na spochybnenie oprávnenosti použit' tento pojem ako definičný. Urobím to za pomoci reprezentatívneho príkladu argumentácie, v ktorej nemusí íst' o riešenie názorovej nezhody, ale o dosiahnutie iného komunikačného ciel’a. V definícii pojmu argumentácie, ktorú navrhnem v záverečnej časti, sa preto pojem riešenia názorovej nezhody nahrádza iným pojmom, ktorý by mal zabezpečit' jej väčšiu všeobecnost'.

\section{Pragmadialektická definícia}

Detailne premyslenú definíciu pojmu argumentácie ponúkajú prívrženci tzv. pragmadialektickej teórie (PDT), ktorá patrí k hlavným prístupom v súčasnom výskume argumentácie. ${ }^{4}$ Znie (pozri van Eemeren et al. 2014, 7):

\footnotetext{
2 Rozlišujem pravdivost' a správnost'. Kým pravdivost' možno pripísat' len stanoviskám, ktoré majú propozičný obsah, správnost' možno pripísat' aj stanoviskám s nepropozičným obsahom.

${ }^{3}$ Presviedčajú nás o tom nielen teoretické práce, ale aj populárne publikácie o argumentácii a kritickom myslení. Jednou z najvydarenejších kníh tohto zamerania, v ktorej sa explicitne poukazuje na všadeprítomnost' argumentácie, je práca Heinrichs (2010).

${ }^{4}$ Zakladatel'mi PDT sú Frans H. van Eemeren a Rob Grootendorst, ku ktorým sa pridali viacerí d’alší teoretici a žiaci. Z najvýznamnejších prác možno spomenút’ van Eemeren, Grootendorst (1992, 2004), van Eemeren ed. (2001), van Eemeren et. al. (2009). Pragmadialektickú koncepciu využil vo svojej analýze uplatňovania abstrakcií a idealizácií v argumentácii Halas (2019).
} 
Argumentácia je komplexná komunikačná a interakčná činnost', zameraná na riešenie názorovej nezhody medzi hovorcom a adresátom prostredníctvom predloženia súboru propozícií, ktoré sa hovorca zaväzuje v prípade potreby obhajovat', s ciel'om urobit' sporné stanovisko prijatel'ným pre racionálnu, rozumne usudzujúcu osobu. ${ }^{5}$

PDT sa zameriava na argumentáciu v reálnych komunikačných situáciách, v ktorých komunikační aktéri uskutočňujú vhodné druhy rečových aktov. Ponúka konceptuálny aparát na opis predkladania, analyzovania a vyhodnocovania výskytov argumentácie, pričom aspekty argumentácie a jej kvalitu hodnotí vzhl’adom na určitý model kritickej diskusie. Ide o abstraktný model, teoretický nástroj, ktorý umožňuje rekonštrukciu reálnych výskytov argumentácie. V tomto článku mi však nejde o hodnotenie tohto modelu a jeho fungovanie, ale len o posúdenie vhodnosti uvedenej definície, ked’že na jej základe sa majú identifikovat' situácie - teda výskyty argumentácie - ktoré sa prípadne majú následne pomocou modelu analyzovat', resp. ktoré sa majú analyzovat' prostriedkami iných teoretických prístupov. ${ }^{6}$

Argumentácia sa používa vtedy, ked' adresáti neprijímajú hovorcovo stanovisko alebo ked' vzniká podozrenie, že ho neprijímajú, teda vtedy, ked' existujú pochybnosti alebo domnelé pochybnosti o správnosti stanoviska (čo sa môže prejavit’ napríklad tým, že niektorý z adresátov ho otvorene odmieta, ale aj tým, že dostatočne neprejaví jeho akceptovanie). Pomocou argumentácie sa má zabezpečit' jeho prijatel'nost' pre osobu, ktorá ho neprijíma. Aktéri argumentácie vystupujú v rôznych rolách - niekto $\mathrm{z}$ nich je proponentom stanoviska, niekto zase vystupuje ako oponent voči nemu. Proponent na seba prijíma záväzok obhajovat' stanovisko, a teda uvádzat' argumenty v jeho prospech. Oponent môže obhajovat' stanovisko, ktoré je nezlučitel'né s proponentovým stanoviskom (a teda aj oponent môže byt' proponentom určitého stanoviska), alebo ho môže spochybňovat' bez toho, aby obhajoval niečo iné.

Hoci sa v definícii hovorí o komplexnej komunikačnej a interakčnej činnosti, nemá to znamenat', že definícia sa aplikuje len na argumentáciu uvedenú v explicitnom dialógu medzi komunikujúcimi partnermi. Dialóg môže byt' len implicitný (pozri van Eemeren, Grootendorst 2004, 21). V tomto zmysle sa aj monológ dá konštruovat' ako forma dialógu, $\mathrm{v}$ ktorej jedna osoba zohráva úlohu proponenta aj oponenta, alebo $\mathrm{v}$ ktorom oponentom je len myslená osoba.

${ }^{5}$ PDT niekedy pracuje aj s odlišnou definíciou, $\mathrm{v}$ ktorej sa pojem riešenia názorovej nezhody objavuje len implicitne (pozri napríklad van Eemeren, Grootendorst 2004, 1; van Eemeren, Henkemans 2017, 1; van Eemeren ed. 2001, 11): „Argumentácia je verbálna, sociálna a racionálna činnost', ktorej ciel'om je presvedčit' rozumného kritika o prijatel'nosti určitého názoru prostredníctvom predloženia jednej alebo viacerých propozícií, ktoré majú odôvodnit' toto stanovisko.“

${ }^{6}$ Nasledujúce zhrnutie niektorých čŕt PDT, ktoré súvisí s uvedenou definíciou, možno nájst’ v ktorejkol’vek z prác spomenutých v poznámke 3 . 
Hoci sa v definícii hovorí o názorovej nezhode medzi komunikačnými partnermi, nemá to znamenat', že nezhoda musí byt' explicitná. Adresát $\mathrm{v}$ skutočnosti nemusí voči proponentovmu stanovisku nič namietnut', no stačí, ak proponent uskutoční v argumentácii kroky na odvrátenie len potenciálneho spochybnenia svojho stanoviska (pozri napríklad van Eemeren, Snoeck Henkemans 2017, 2 - 3). Možno to vel'mi dobre vztiahnut' práve na výskyt argumentácie v monológu. Proponent nemusí reálne vzniest' námietku voči svojmu stanovisku, no stačí, ked' berie na zretel' možnost' existencie nejakej námietky, a preto svoje stanovisko podporí argumentáciou.

Zameranost' na riešenie názorovej nezhody sa môže javit' ako inherentná vlastnost' všetkých prípadov argumentácie, a preto sa môže zdat', že definícia pojmu argumentácie by mala tento aspekt zachytávat'. ${ }^{7}$ Nazdávam sa však, že hoci to platí o mnohých prípadoch argumentácie, vyskytujú sa aj situácie, v ktorých sa jej použitie nespája s riešením názorovej nezhody. Pokúsim sa to obhájit' analýzou modelového prípadu a ukážem, ako ho možno d’alej extrapolovat'. Dôsledkom týchto úvah je konštatovanie, že idea riešenia názorovej nezhody by nemala byt' súčastou všeobecnej definície pojmu argumentácie. V tejto súvislosti však treba upozornit', že mojím ciel'om nie je spochybnit' definície pojmu argumentácie v kontexte PDT. Nasledujúce úvahy sa pohybujú mimo rámca PDT aj mimo akéhokol'vek iného teoretického rámca. Ide mi skôr o to, že uvedená definícia nie je vhodná ako dostatočne všeobecný nástroj na identifikáciu komunikačných aktov, ktoré by sa následne mali pomocou nejakého teoretického prístupu analyzovat ako výskyty argumentácie.

\section{Argumentácia a názorová nezhoda}

Argumentácia sa sústred’uje na obhajobu určitého stanoviska, pričom proponent ho spravidla obhajuje preto, aby o jeho prijatel'nosti presvedčil (skutočného alebo hypotetického) adresáta, ktorý k nemu môže zaujímat' antagonistický postoj, a odstránil tak (aspoň potenciálnu) názorovú nezhodu. Zámerne sa v predošlej vete vyskytuje slovo „spravidla“, pretože tvrdím, že nie každý výskyt argumentácie musí mat' za ciel' presvedčit' adresáta o prijatel'nosti hovorcovho stanoviska a eliminovat' názorovú nezhodu. Inými slovami, bezpochyby existuje tesná korelácia medzi argumentáciou a riešením názorovej nezhody, táto väzba však nie je konceptuálnej či analytickej povahy, ale ide len o empirickú koreláciu s vysokou frekvenciou výskytu.

\footnotetext{
${ }^{7}$ Treba povedat', že idea riešenia názorovej nezhody sa v rôznych variáciách využíva aj v iných prístupoch. Napríklad D. Walton poukazuje na to, že „základným účelom argumentácie je predloženie dôvodu [...] v prospech tvrdenia, ktoré je predmetom pochybnosti, a teda odstránenie tejto pochybnosti“" (Walton 2006, 1). Podobne T. Govier tvrdí, že ,argumenty sa dajú nájst’ tam, kde sa vyskytuje spor alebo nezhoda o nejakom predmete a kde sa l'udia usilujú túto nezhodu racionálne vyriešit"“ (Govier 2010, 1). Pojem nezhody nebudem podrobnejšie tematizovat', no niektoré súvislosti medzi argumentáciou a druhmi nezhôd sú predmetom state (Bielik 2019).
} 
Svoje tvrdenie o nekonceptuálnej povahe väzby medzi výskytom argumentácie a riešením názorovej nezhody budem overovat' nasledujúcim spôsobom. Skonštruujem modelovú situáciu, v ktorej proponent predstaví stanovisko a argumentuje v jeho prospech. Potom budem predpokladat', že on sám alebo adresát uskutočnia rečový akt, ktorého obsah poprie zameranie proponentovej argumentácie na riešenie názorovej nezhody o tomto stanovisku. Ak sa uskutočnením tohto rečového aktu do komunikácie nezavedie prvok, ktorý by akýmkol'vek spôsobom narúšal konzistentnost' prebiehajúcej komunikácie alebo by jej zmysluplné pokračovanie blokoval, je to signál, že popretie zámeru riešit' názorovú nezhodu je prípustné. Ukáže sa tak, že proponentova argumentácia môže mat' iný ciel' ako riešenie názorovej nezhody. Na základe toho bude možné konštatovat', že vzt’ah medzi výskytom argumentácie a riešením názorovej nezhody má povahu empirickej korelácie, nie konceptuálnej nutnosti.

\subsection{Modelový príklad}

Existujú situácie, v ktorých sa na prvý pohl'ad môže zdat', že medzi hovorcom a adresátom nie je názorová nezhoda o určitom stanovisku, no hovorca predkladá argumenty jeho v prospech. V takýchto situácia sa teda na prvý pohl'ad zdá, že výskyt argumentácie nemôže mat' za ciel' riešenie názorovej nezhody. Naozaj však takéto zdanie možno pokladat' za evidenciu v prospech neexistencie konceptuálnej väzby medzi výskytom argumentácie a riešením názorovej nezhody?

Takéto prípady možno nájst' vo viacerých druhoch situácií. Jednu z nich môže predstavovat' čast' interakcie medzi učitel’om a žiakom na skúške. Predpokladajme, že pri konkrétnej skúške učitel' položí otázku a žiak na ňu odpovie, pričom táto situácia sa vyznačuje nasledujúcimi atribútmi:

a) na učitel'ovu otázku existuje správna odpoved',

b) učitel' vie, že na jeho otázku existuje správna odpoved',

c) učitel' ju ako správnu odpoved' na svoju otázku akceptuje,

d) žiak vo svojej reakcii na učitel'ovu otázku uvedie túto odpoved',

e) žiak vie, že vo svojej reakcii uviedol správnu odpoved',

f) učitel' vie, že žiak vo svojej reakcii uviedol správnu odpoved',

g) žiak vie, že učitel' vie, že žiak vo svojej reakcii uviedol správnu odpoved',

h) učitel' vie, že žiak vie, že učitel' vie, že žiak vo svojej reakcii uviedol správnu odpoved'.

Správna odpoved' na otázku predstavuje stanovisko, ktoré obidvaja účastníci komunikácie zastávajú, sú jeho proponentmi. Ked’že zastávajú rovnaké stanovisko, je medzi nimi názorová zhoda. Na základe toho, čo sa konštatuje v bodoch g) a h), takisto vedia, že medzi nimi je názorová zhoda. Bez ohl'adu na názorovú zhodu však učitel' žiaka vyzve, aby argumentoval v prospech daného stanoviska. Žiak tejto 
požiadavke vyhovie a uvedie argument. Rozhovor medzi nimi teda môže mat' nasledujúcu štruktúru:

(1) Učitel': [otázka]

Žiak: [odpoved']

Učitel': Správne. Uved' argument, ktorým svoju odpoved' zdôvodníš.

Žiak: [odpoved']

Učitel' svoju požiadavku na uvedenie argumentu nedáva preto, že by so stanoviskom nesúhlasil alebo by ho akokol'vek spochybňoval a potreboval by na zmenu svojho názoru d'alšie presviedčanie.

Zdá sa teda, že máme prípad, v ktorom sa vyskytuje argumentácia bez názorovej nezhody, ktorá by sa mala argumentáciou rozriešit'. Ak je to tak, spojenie medzi výskytom argumentácie a existenciou názorovej nezhody je vol'nejšie, než sa môže zdat' na základe definície pojmu argumentácie.

\section{2. Štylizovaná alebo implicitná názorová nezhoda}

Niekto by mohol namietnut', že hoci učitel' v modelovom príklade nevystupuje ako reálna a explicitná opozícia voči žiakovi, predsa len možno túto situáciu interpretovat' tak, aby sa v nej použitie argumentácie spojilo so zámerom riešit' názorovú nezhodu. Nemohol by učitel' napríklad byt' len imaginárnou alebo implicitnou opozíciou?

Prvý pokus o takúto interpretáciu tkvie v tom, že učitel' hrá rolu oponenta, aj ked' so žiakovým stanoviskom súhlasí. Výzvu na predloženie argumentu v prospech stanoviska adresuje žiakovi preto, že sa štylizuje do úlohy jeho oponenta, hoci ním v skutočnosti nie je. Žiak sa stáva proponentom stanoviska v domnelej diskusii so štylizovaným oponentom. Takáto interpretácia je bezpochyby možná, no určite si možno predstavit' skúšku, pri ktorej žiak nepouživa argumentáciu takýmto spôsobom. Učitel' totiž môže žiaka vyzvat' na predloženie argumentu v prospech svojho stanoviska, a pritom explicitne popriet', že by sa štylizoval do pozície oponenta, ked' vyhlási:

(2) Nebudem predstierat' spochybňovanie stanoviska, ktoré si predložil, napriek tomu však uved' v jeho prospech nejaký argument.

Takáto výzva je konzistentná. Žiak vie, ako na ňu adekvátne reagovat', a teda sa nedostane do bezvýchodiskovej situácie - napriek učitel'ovej výzve bude vediet' argumentovat', hoci vie, že jeho komunikačný partner nie je jeho skutočným oponentom, ba ani sa do tej roly neštylizuje. To značí, že je konzistentné, aby (i) učitel' v skutočnosti súhlasil so žiakom, (ii) poprel, že hrá rolu oponenta, a (iii) vyzval žiaka na predloženie argumentu, pričom (iv) žiak nebude mat' žiadne pochybnosti o tom, čo sa od neho chce a ako na takúto výzvu reagovat'. 
Druhý pokus o spomenutú interpretáciu tkvie v tom, že učitel' sa síce vedome neštylizuje do úlohy oponenta, no napriek tomu $\mathrm{v}$ danej situácii predstavuje aspoň implicitného oponenta, a to bez toho, aby si to musel uvedomovat' alebo nejako inak brat' do úvahy. Implicitným oponentom je totiž už preto, že žiaka skúša a vyžaduje od neho plnenie úloh vrátane úlohy predkladat' argumenty v prospech svojich tvrdení. Preto možno povedat', že hoci názorová nezhoda nie je explicitná, je aspoň implicitná, obsiahnutá v charaktere situácie. Opät' je zrejmé, že takáto interpretácia je možná. Zároveň je však zrejmé aj to, že je myslitel'né, aby učitel' nebol ani len implicitným oponentom, pretože môže konzistentne vyhlásit’:

(3) S tvojím stanoviskom súhlasím a nemám voči nemu žiadne výhrady, napriek tomu však uved' v jeho prospech nejaký argument.

Učitel' takto prejaví súhlas so žiakom. Možnost' len implicitného nesúhlasu je tak prekonaná explicitným súhlasom. Požiadavka, ktorú žiakovi adresuje učitel’ svojou výpoved'ou (3), je však pre žiaka plne pochopitelná a splnitel'ná. Žiak vie, že má argumentovat', hoci vie aj to, že učitel' s ním súhlasí. Je teda konzistentné, aby (i) učitel' explicitne súhlasil so žiakom, (ii) poprel tak existenciu aspoň implicitného nesúhlasu, a (iii) vyzval žiaka na predloženie argumentu, pričom (iv) žiak nebude mat' žiadne pochybnosti o tom, čo sa od neho chce a ako na takúto výzvu reagovat'.

\subsection{Hypotetická názorová nezhoda}

Obidva pokusy o interpretáciu modelovej situácie, ktorá by bola v súlade s definíciou pojmu argumentácie podl'a PDT, sú postavené na predpoklade, podla ktorého názorová nezhoda nemusí byt' zjavná. Tieto pokusy nie sú úspešné, no existuje aj tretia možnost', ktorá by sa mohla použit' na lepšiu obhajobu definície. Vychádza z toho, že hoci komunikácia prebieha medzi učitel'om a žiakom, nie je nevyhnutné, aby pozíciu oponenta voči žiakovmu stanovisku zastával práve učitel'. Oponentom môže byt' l'ubovol'ná, hoci aj neprítomná, alebo len hypotetická osoba, a fakt, že žiak predkladá argumenty v prospech stanoviska, signalizuje zámer riešit' názorovú nezhodu s akýmkol'vek, hoci aj neprítomným, alebo len hypotetickým oponentom. Ako konštatujú prívrženci PDT, „ciel’om argumentácie je vždy presvedčit' potenciálnych kritikov bez ohl'adu na to, či sú alebo nie sú skutočne prítomni““ (van Eemeren, Henkemans 2017, 24). To značí, že žiak predkladá argumenty v prospech svojho stanoviska preto, aby odvrátil názorovú nezhodu, ktorá nemusí byt’ skutočná, ale stačí, ak je len potenciálna.

Táto obhajoba definície je pomerne silná, no napriek tomu nedokazuje, že medzi výskytom argumentácie a úmyslom riešit' názorovú nezhodu musí byt' pevnejší vzt’ah ako empirická korelácia. Vieme si totiž predstavit', že v určitej fáze výmeny medzi učitel'om a žiakom v našej modelovej situácii učitel' vyhlási: 
(4) V poriadku, doteraz si uviedol argumenty, ktoré sú dostatočne presvedčivé pre kohokolvvek, a teda každý musí tvoje stanovisko akceptovat' bez výhrad. Len pre zaujímavost' sa pýtam, či vieš uviest' aj d’alšie argumenty v jeho prospech. ${ }^{8}$

Touto replikou učitel' explicitne konštatuje neexistenciu oponenta - skutočného ani len hypotetického - a teda nastaví špecifické parametre komunikačnej situácie, v ktorej nevzniká potreba riešit' názorovú nezhodu. Napriek tomu však vyzýva na d'alšiu argumentáciu. Keby sa použitie argumentácie malo analyticky viazat' na riešenie názorovej nezhody, žiak by sa mal dostat' do situácie, v ktorej by nemal byt' schopný adekvátnej reakcie, teda nemal by vediet', ako na túto repliku nadviazat' - nanajvýš by mohol vyhlásit', že v danom kontexte nerozumie požiadavke. Ved' učitel' od neho požaduje nemožné - riešit' nezhodu, ktorá neexistuje. Je však zrejmé, že žiak nemusí túto situáciu vyhodnotit' ako nemožnú. Skôr naopak, bude schopný nad’alej uvádzat' argumenty v prospech svojho stanoviska, a teda sa bude správat' podl'a očakávaní, hoci svojimi d’alšími príspevkami do diskusie nebude mat' $\mathrm{v}$ úmysle prispievat' $\mathrm{k}$ riešeniu názorovej nezhody. Navyše žiak môže opísat' svoju aktivitu, ktorú uskutoční v reakcii na vyhlásenie (4), nasledujúcimi slovami, a to bez toho, aby povedal čokolvek nekonzistentné:

(5) Viem, že s mojím stanoviskom všetci súhlasia, a teda neexistuje názorová nezhoda o ňom, no napriek tomu $\mathrm{v}$ jeho prospech argumentujem.

Zdá sa teda, že je možné zmysluplne argumentovat' bez toho, aby sa touto činnost'ou mala riešit' názorová nezhoda.

$\mathrm{Na}$ vyjasnenie dodávam, že nepopieram existenciu prípadov, v ktorých sa žiakova odpoved' na skúške dá interpretovat' ako pokus riešit' názorovú nezhodu s hypotetickým oponentom. Tvrdím len to, že nie je nevyhnutné interpretovat' ich takýmto spôsobom. Pripúšt’am, že takýchto prípadov nemusí byt' vel’a, ba dokonca nie je ani potrebné, aby sa aj naozaj vyskytli; podstatné je len to, že sú myslitel’né, čo postačuje ako dôkaz neexistencie konceptuálnej väzby medzi výskytom argumentácie a riešením názorovej nezhody.

\footnotetext{
${ }^{8} \mathrm{~V}$ predchádzajúcej verzii článku som namiesto druhej vety v (4) uvádzal otázku: „Aké d’alšie argumenty v jeho prospech dokážeš uviest?"“ Anonymný/-á recenzent/-ka namietal/-a, že vyhlásenie (4) je pragmaticky nekonzistentné, pričom konštatuje: „Nezdá se konzistentní deklarovat akceptaci stanoviska, tj. zbavení se pochybností, a zároveň po někom vyžadovat předkládání další argumentace, která mně má zbavit pochybností. "Hoci nesúhlasím s tým, že by išlo o pragmaticky nekonzistentnú dvojicu viet, resp. rečových aktov uskutočnených ich použitím (pragmaticky sa môžu javit' ako nekonzistentné len preto, že argumentácia sa automaticky považuje za nástroj na zbavenie sa pochybností, čo by sa však malo najprv dostatočne preukázat', pričom tento článok je zameraný na odmietnutie tohto postoja), upravil som vyhlásenie (4) tak, aby bolo zrejmé, že učitel' vyžaduje d’alšiu argumentáciu len zo záujmu, nie preto, aby žiak pokračoval v presviedčaní prípadných oponentov. Vzhl'adom na takúto situáciu ani žiakova výpoved' (5) (uvedená d’alej v texte) nie je pragmaticky nekonzistentná.
} 


\subsection{Len zdanlivá argumentácia}

S modelovou situáciou sa možno vysporiadat' aj inak. Niekto by mohol tvrdit', že sa len zdá, že žiak argumentuje, no v skutočnosti argumentácia sa v nej nevyskytuje. Presnejšie povedané, ak hovorcovu výpoved', ktorou sa nepokúša riešit' skutočnú názorovú nezhodu so skutočným komunikačným partnerom, nemožno pokladat' za pokus riešit' ani len štylizovanú, implicitnú či hypotetickú názorovú nezhodu (resp. inú náhradu namiesto skutočnej názorovej nezhody, ktorá nie je pokrytá v predošlých úvahách), nemožno takúto výpoved' interpretovat' tak, že obsahuje argumentáciu.

Takémuto vysvetleniu by mohli nahrávat' aj niektoré tézy PDT. Podla PDT argumentácia je rečový akt a podobne ako ostatné rečové akty, aj ona musí spíńat' určité podmienky (van Eemeren, Henkemans 2017, 46). Medzi prípravné podmienky rečového aktu argumentácie sa zarad'uje podmienka, podl'a ktorej ,,argumentujúci musí verit', že adresát zatial' úplne neakceptuje dané stanovisko“ (ibid.). Na základe toho by sa dalo povedat', že ak v modelovej situácii nie je nikto, skutočný ani len hypotetický, kto by mal pochybnosti o danom stanovisku, tak nejde o argumentáciu v pravom zmysle slova. Rečový akt, ktorý žiak uskutoční, treba klasifikovat' ako akt iného druhu.

Voči tejto interpretácii možno namietnut' dvoma spôsobmi. Po prvé, prívrženci PDT k uvedenej podmienke dodávajú, že ak nie je splnená, argumentácia je redundantná (ibid.). Ak je argumentácia redundantná, neznamená to, že sa neuskutočnila, ale iba to, že jej účelom nie je presvedčit' adresáta o akceptovaní istého stanoviska. PDT má teda teoretické zdroje na to, aby uznala ako argumentáciu aj také rečové akty, ktorých ciel’om nie je riešit' názorové nezhody. V tejto súvislosti sa však vynára otázka, načo sa v definícii pojmu argumentácie vyskytuje podmienka riešenia názorovej nezhody. Tento interný problém PDT však nie je dôležitý.

Klúčovou je druhá námietka proti tejto interpretácii. Aj keby sme pripustili, že žiak v takejto situácii neargumentuje v pravom zmysle slova, teda neuskutočňuje rečový akt argumentácie, predsa len by sme museli uznat', že uvádza argumenty. To značí, že uvádzat' argumenty by nemuselo byt' to isté ako argumentovat'. Odhliadnuc od toho, že takto sa zavádza nie príliš jasné rozlíšenie, môžu vznikat' neintuitívne interpretácie niektorých situácií. Vezmime si nasledujúci modelový príklad. Hovorca uvedie stanovisko a adresát ho spochybní námietkou; vzápätí hovorca predloží argument $\mathrm{v}$ prospech stanoviska, ktorým zároveň vyvráti námietku; potom predloží d’alší argument, ktorým adresáta presvedčí o prijatel’nosti stanoviska, pričom adresát dá najavo, že hovorca ho presvedčil. V obidvoch prípadoch hovorca uskutočňuje rečový akt argumentácie, pričom dosiahol požadovaný efekt, a vie, že dosiahol požadovaný efekt. Napriek tomu však hovorca vzápätí pokračuje d'alej a uvedie ešte d'alší argument, hoci adresát už voči stanovisku nenamieta, nemá voči nemu pochybnosti, ba dokonca ho akceptuje, a hovorca o tom vie. Hovorca to môže urobit' napríklad preto, 
aby ilustroval, že v prospech stanoviska sú $\mathrm{k}$ dispozícii aj d’alšie dôvody. V takom prípade by sme však mali konštatovat', že hovorca už neuskutočnil rečový akt argumentácie. To nie je intuitívne. Vhodnejšie je zrejme konštatovanie, že vo všetkých troch prípadoch hovorca argumentuje, hoci sleduje rôzne ciele. ${ }^{9}$

\subsection{Iné príklady}

Prvý príklad som analyzoval podrobnejšie, aby bola zjavná stratégia, ako možno konštruovat' situácie, $v$ ktorých sa výskyt argumentácie nemusí spájat's existenciou názorovej nezhody. Podobných prípadov sa dá vymysliet' viac. V hrubých rysoch načrtnem ešte dva takéto prípady.

Pred chvíl'ou som poukázal na to, že hovorca môže uviest' nový argument v prospech nejakého stanoviska, hoci sa mu podarilo adresáta o tomto stanovisku presvedčit' už v skoršej fáze dialógu. Tento jav možno zovšeobecnit'. Uvádzanie d’alších argumentov v prospech určitého stanoviska v dialógu s komunikačnými partnermi, ktorí toto stanovisko akceptujú, možno zmysluplne chápat' rôzne: môže íst' o pokus zdôvodnit' stanovisko alternatívnymi spôsobmi, môže íst' o pokus obohatit' argumentačnú bázu komunikačných partnerov, môže íst' o pokus posilnit' presvedčenie o prijatel'nosti stanoviska atd'. ${ }^{10}$ Posilnenie presvedčenia o prijatel'nosti stanoviska nemusí byt' automaticky spojené s odstraňovaním prípadných pochybností o tomto stanovisku. Hovorca môže argumenty uvádzat' preto, lebo môže byt' presvedčený o tom, že budú pre adresáta zaujímavé či podnetné, nie preto, že by adresáta mali presvedčit' o niečom, čo zatial' neakceptuje, alebo o čom pochybuje. V takomto prípade sa adresát dozvedá nové dôvody v prospech stanoviska bez toho, aby sa tým jeho epistemický postoj musel k stanovisku akokol'vek menit'. Hovorca môže d'alej argumentovat' v takýchto situáciách bez toho, aby tým sledoval zámer eliminovat' skutočnú, alebo aspoň potenciálnu názorovú nezhodu.

Iným prípadom, $\mathrm{v}$ ktorom sa výskyt argumentácie nespája so zámerom riešit' názorovú nezhodu, je ilustratívne použitie argumentácie. V určitých kontextoch môže hovorca uskutočnením rečového aktu argumentácie adresátovi ukazovat', aké dôvody jeho samého presvedčili, aby stanovisko akceptoval, a to bez toho, aby mal v úmysle presviedčat' o ňom skutočného, alebo len hypotetického oponenta. Hoci štandardným spôsobom, ako niekomu podat' správu tohto druhu, je jednoduchý opis situácie, v ktorej sa argumentácia uskutočnila (,Stanovisko S som akceptoval preto, lebo bol uvedený dôvod D“), predsa len možno pripustit’, že hovorca môže namiesto toho argumentáciu priamo použit' (nielen sa o nej zmienit'). V takom prípade argumentáciu

\footnotetext{
${ }^{9}$ Rovnako nie je príliš intuitívne povedat', že pri tret’om argumente hovorca mení adresáta a tretí argument je zameraný na presvedčenie len štylizovaného, implicitného alebo hypotetického oponenta. ${ }^{10}$ Využitie argumentácie na takýto účel spomína napríklad (Sobek 2008, 18).
} 
zopakuje, no nebude to robit's ciel'om presvedčit' adresáta, ale len ukáže, aké dôvody jeho presvedčili. Táto argumentácia bola použitá s ciel'om niekoho presvedčit' - konkrétne súčasného hovorcu - v pôvodnej situácii, v ktorej bol súčasný hovorca oponentom, no nie v situácii, v ktorej len niekomu d’alšiemu reprodukuje, čo sa v pôvodnej situácii odohralo. ${ }^{11}$

Možno uznat', že pre PDT nie sú tieto druhy využívania argumentácie zaujímavé, a preto aj definícia pojmu argumentácie je sformulovaná tak, že sa na ne nevzt'ahuje. Ak je to tak, ide o legitímnu obhajobu pojmu argumentácie podla PDT. Keby sme však chceli tento pojem argumentácie vytrhnút' z kontextu PDT a preniest' ho do iného prostredia, $\mathrm{v}$ ktorom sa argumentácia chápe širšie, nemohli by sme dobre zdôvodnit', prečo by sa spomenuté spôsoby použitia argumentov nemali považovat' za prípady argumentácie. $^{12}$

\section{Záver: všeobecný pojem argumentácie}

V definícii pojmu argumentácie podla PDT sa riešenie názorovej nezhody medzi komunikačnými partnermi považuje za hlavný ciel' argumentácie. Ako sme však videli, v niektorých prípadoch výskyty argumentácie môžu mat' iné ciele a pokusy vtesnat' ich do tohto rámca nedávajú dobrý zmysel. To značí, že definícia pojmu argumentácie podl'a PDT nie je dostatočne vhodná na to, aby sa dala používat' ako všeobecná definícia, teda aj mimo PDT. Všeobecná definícia by mala obsahovat' zmienku o parametroch, ktoré sa musia nájst’ $v$ každom výskyte argumentácie.

V definícii podl’a PDT sa argumentácia charakterizuje ako činnost', ktorá je zameraná na riešenie názorovej nezhody medzi proponentom a oponentom o určitom stanovisku. V tejto formulácii sú fakticky implicitne prítomné dve veci - na jednej strane pri argumentácii ide o obhajobu stanoviska a na druhej strane sa touto obhajobou

${ }^{11}$ Podstata prípadu tohto druhu tkvie v tom, že hovorca len demonštruje, ako sa niekomu podarilo presvedčit' ho o určitom stanovisku, no nevykonáva rečový akt, ktorého ciel'om je niekoho - konkrétne jeho samého - presvedčit' o danom stanovisku. Hovorca teda demonštruje, ako sa riešila určitá názorová nezhoda, no svojou aktuálnou výpoved’ou nemá v úmysle riešit' názorovú nezhodu.

12 Tieto úvahy proti pragma-dialektickej definícii anonymný/-á recenzent/-ka spochybnil/-a. Tvrdí, že aj ked' reálne argumenty nemusia byt' zamerané na riešenie názorovej nezhody, PDT ich rekonštruuje, akoby išlo o prípady názorovej nezhody pomocou svojho modelu kritickej diskusie, aby sa ukázalo, ktoré prvky diskurzu funkcionálne prispievajú k riešeniu názorovej nezhody. S tým možno len súhlasit'. Problém je však v niečom inom - v tom, že ak pomocou definície máme identifikovat' úseky komunikácie, ktoré sú prípadmi argumentácie, tak ich identifikácia prostredníctvom pojmu riešenia názorovej nezhody spôsobí, že niektoré zjavné prípady argumentácie nám uniknú. Na ich identifikáciu musíme použit iný pojem argumentácie, a preto pojem definovaný v PDT nie je jeho vhodným explikátom. Definícia by nám mala v prvom rade umožnit' identifikovat' všetky prípady, ktoré intuitívne chceme považovat' za prípady argumentácie, a následne na ne môžeme aplikovat' analytické nástroje určitého teoretického prístupu. Problém s uvedenou definíciou teda vzniká vtedy, ked' ho chceme použit' na vyčlenenie materiálu, ktorý by sa mal spracovat' prostriedkami PDT, nie vtedy, ked' sa prostriedky PDT na vyčlenený materiál už aplikujú. 
má dosiahnut' zjednotenie postojov k nemu. Príklady, ktoré som uviedol, potvrdzujú čast', ktorá sa týka obhajoby stanoviska, no nepotvrdzujú čast', ktorá sa týka zjednotenia postojov. Všeobecný pojem argumentácie sa teda môže vymedzit' prostredníctvom pojmu obhajoby stanoviska, ${ }^{13}$ no bolo by riskantné, keby sa vymedzoval aj zmienkou o konkrétnych účeloch, na ktoré obhajoba stanoviska môže slúžit'. ${ }^{14}$

Iste, je možné pripustit', že obhajoba stanoviska môže hovorcovi slúžit' na d'alšie účely, no bližšie ich konkretizovat' by vo všeobecnej definícii nebolo vhodné. Všeobecná definícia pojmu argumentácie môže teda zniet':

Argumentácia je komplexná komunikačná a interakčná činnost', zameraná na obhajobu určitého stanoviska prostredníctvom predloženia súboru propozícií, ktoré sa hovorca zaväzuje $\mathrm{v}$ prípade potreby obhajovat' $\mathrm{s}$ úmyslom dosiahnut' komunikačné ciele dané povahou situácie.

Komunikačné ciele dané povahou situácie môžu byt' rozmanité. Vel'mi rozšíreným ciel’om je riešenie názorovej nezhody medzi komunikačnými partnermi. Možno ho identifikovat' v podstate vždy, ked' argumentácia je súčast'ou kritickej diskusie, teda vždy, ked' adresát spochybní určité stanovisko a hovorca reaguje na explicitné alebo implicitné spochybnenie stanoviska. Tento ciel' je častý, no to neznamená, že medzi výskytom argumentácie a riešením názorovej nezhody je tesnejší vzt’ah ako empirická korelácia.

Príklady z predchádzajúcej časti naznačujú, že komunikačnými ciel’mi môžu byt' aj iné efekty. Hovorca môže mat' v úmysle napríklad adresátovi ukázat', že má svoje stanovisko zdôvodnené (a teda ho neakceptuje len ako číry predpoklad alebo na základe predsudkov a podobne) alebo že má určité poznatky. To môže byt' prípad žiaka, ktorý odpovedá na skúške. Hovorca môže d'alej mat' v úmysle adresátovi ukázat', že existujú aj iné dôvody v prospech určitého stanoviska, než sú tie, ktoré adresát pozná a na základe ktorých stanovisko akceptuje. Hovorca zároveň môže mat' v úmysle adresátovi reprodukovat', aké dôvody jeho samého podnietili akceptovat' stanovisko, pričom aktuálnou argumentáciou hovorca nepresviedča ani seba, ani nikoho d'alšieho. Nie je problém vymýšl'at' aj d’alšie dôvody, prečo použit'v komunikácii argumentáciu. ${ }^{15}$

\footnotetext{
${ }^{13} \mathrm{~V}$ konkurencii s inými prístupmi, ktoré sa v teórii argumentácie predložili, obhajuje takéto chápanie napríklad Blair $(2012,189)$. Podobne v našom jazykovom prostredí sa argumentácia ako určitý druh uvádzania dôvodov v prospech tézy chápe v Schmidt et al. $(2018,17)$.

${ }^{14}$ Priznávam, že v práci Buček a Zouhar $(2015,142,144)$ sme toto riziko podstúpili a prezentovali vymedzenie pojmu argumentácie, ktoré je vel’mi podobné vymedzeniu v rámci PDT. V súčasnosti by som postupoval opatrnejšie.

${ }^{15}$ O mnohých možnostiach využitia argumentácie sa možno dočítat' napríklad v Blair (2012, 187 - 188).
} 
Na záver teda možno konštatovat', že hoci definícia pojmu argumentácie podl’a PDT môže vyhovovat' účelu, ktorý sa sleduje v rámci PDT, argumentácia sa vyskytuje aj v iných podobách, a preto je potrebný aj všeobecnejší pojem argumentácie.

\section{Literatúra}

BIELIK, L. (2019): Druhy nezhody a ich (semi)formálna rekonštrukcia. Filozofia 74 (9), 690 - 704. DOI: https://doi.org/10.31577/filozofia.2019.74.9.1

BLAIR, J. A. (2012): Groundwork in the Theory of Argumentation. Dordrecht: Springer.

BUČEK, J., ZOUHAR, M. (2015): Argumentácia a médiá. Bratislava: Vydavatel'stvo UK.

GOVIER, T. (2010): A Practical Study of Argument. 7. vydanie. Belmont, CA: Wadsworth.

HALAS, J. (2019): Abstrakcia, idealizácia a používanie argumentov. Filozofia 74 (9), 705 - 720. DOI: https://doi.org/10.31577/filozofia.2019.74.9.2

HEINRICHS, J. (2010): Winning Arguments: From Aristotle to Obama - Everything You Need to Know about the Art of Persuasion. London: Penguin Books.

SCHMIDT, M., ŠEDÍK, M, TALIGA, M. (2018): Ako správne argumentovat', písat' a diskutovat'. Banská Bystrica: Belianum.

SOBEK, T. (2008): Argumenty teorie práva. Praha-Plzeň: Vydavatelství a nakladatelství Aleš Čeněk, s. r. o.

VAN EEMEREN, F. H., GROOTENDORST, R. (1992): Argumentation, Communication, and Fallacies: A Pragmadialectical Perspective. Hillsdale, New Jersey: Lawrence Erlbaum Associates. DOI: https://doi.org/10.4324/9781315538662

VAN EEMEREN, F. H., GROOTENDORST, R. (2004): A Systematic Theory of Argumentation: The Pragmadialectical Approach. Cambridge: Cambridge University Press. DOI: https://doi.org/10.1017/CBO9780511616389

VAN EEMEREN, F. H., SNOECK HENKEMANS, A. F. (2017): Argumentation: Analysis and Evaluation. 2. vydanie. Oxford: Routledge. DOI: https://doi.org/10.4324/9781315401140

VAN EEMEREN, F. H., GARSSEN, B., MEUFFELS, B. (2009): Fallacies and Judgments of Reasonableness: Empirical Research Concerning the Pragmadialectical Discussion Rules. Dordrecht: Springer. DOI: https://doi.org/10.1007/978-90-481-2614-9

VAN EEMEREN, F. H., GARSSEN, B., KRABBE, E. C. W., SNOECK HENKEMANS, A. F., VERHEIJ, B., WAGEMANS, J. H. M. (2014): Handbook of Argumentation Theory. Dordrecht: Springer. DOI: https://doi.org/10.1007/978-90-481-9473-5

VAN EEMEREN, F. H. (ed.) (2001): Crucial Concepts in Argumentation Theory. Amsterdam: Amsterdam University Press.

WALTON D. (2006): Fundamentals of Critical Argumentation. Cambridge: Cambridge University Press. DOI: https://doi.org/10.1017/CBO9780511807039

Táto práca bola podporená Agentúrou na podporu výskumu a vývoja na základe zmluvy č. APVV-17-0057.

Marián Zouhar

Filozofická fakulta UK v Bratislave

Katedra logiky a metodológie vied

Gondova 2

81102 Bratislava 1

Slovenská republika

e-mail: marian.zouhar@uniba.sk

ORCID: https://orcid.org/0000-0003-2455-8722 